"Thiverval "strain was injected into ro sows at the and or 3 rd month of pregnancy. The strain has no unfavorable effects on the development of pregnancy or on the quality of the offspring. The IO2 piglets born showed normal growth rates and were fully susceptible to vaccination or to challenge carried out at the 3 rd month. This suggests that there is no active immunity induced in utero.

Innocuity for pig embryo suggests that the "Thiverval " strain is devoid of residual virulence.

\title{
LA RÉPONSE IMMUNITAIRE DU JEUNE PORCELET
}

\author{
P. ROUZE
}

Station de Vivologie et d'Immunologie, I. N. R. A., 78850 Thiverval Grignon

\section{RÉSUMÉ}

Le porcelet, immunocompétent à la naissance, n'est pourtant protégé qu'après l'ingestion de colostrum maternel. L'immunité passive ainsi acquise a pour conséquence de s'opposer à l'immunisation active. Ceci conduit, dans la pratique courante à vacciner les porcelets tardivement alors qu'ils ont traversé une période de protection insuffisante.

Cet article rapporte des résultats expérimentaux préliminaires où une immunisation active par un antigène protéique, le lysozyme, a pu être déclanchée chez des porcelets pourvus d'une forte immunité d'origine colostrale.

Dans le but de maintenir les animaux protégés tout au long de leur vie économique, la généralisation de tels résultats ouvrirait la perspective d'une pratique vaccinale précoce.

\section{SUMMARY}

\section{IMMUNOLOGIC RESPONSE IN YOUNG PIGLETS}

Fully immunocompetent at birth, the piglet is only protected after ingestion of maternel colostrum. However, this passive immunity is antagonistic to an active specific immunization. In the field practice, the vaccination of piglets takes place late, after disappearance of the passive antibodies which results in a more susceptible period in the animals'life, before and during weaning.

This paper presents some preliminary experiments which show that an active immune response against a proteic antigen, lysozyme, has been induced in piglets presenting a high specific colostral immunity.

In the purpose of a continuous protection of pigs all along their life, our results offer the possibi vaccinations very soonlity of after birth, whatever the immunological status of the animal. 